\title{
FEMALE OBJECTIFICATION IN TWO SHORT STORIES BY EMILIA PARDO BAZÁN
}

\author{
SUSAN WALTER \\ University of Denver \\ swalter@du.edu \\ ORCID: 0000-0003-1911-2582
}

\section{ABSTRACT}

In two short stories by the canonical author Emilia Pardo Bazán, "Primer amor" and "La argolla" we find a double-voiced discourse, which Elaine Showalter has suggested is very common in women's fiction (1981: 204). In both of Pardo Bazán's tales there are small objects that symbolically allude to women's objectification in the patriarchal society of the time. The dialogue created between these two tales is noteworthy for a number of reasons, including their critical portrayals of romantic relationships, their symbolism, descriptive language and the narrative techniques employed. In this study I posit that both tales critique the objectification of women by the patriarchal society of the time by linking society's tendency to objectify women with symbolic references to confinement.

KEYWORDS: Emilia Pardo Bazán, short fiction, female objectification, confinement.

This study analyzes the short fiction of the late nineteenth and early twentieth century Galician writer and intellectual Emilia Pardo Bazán. The Countess Pardo Bazán is most well known for her canonical novels Los Pazos de Ulloa (1884) and La madre naturaleza (1885), which are often considered naturalist works that helped to introduce the Spanish reading public to this French literary style. She also published short stories, plays, poetry, novellas, and journalism; she even single-handedly edited, wrote and published her own journal Nuevo Teatro Crítico from 1891-1893, where scholars believe she circulated her most forthright feminist works (Tolliver 1998: 64). What has drawn the most critical attention to her work in the past two to three decades is its critique of traditional social mores that limited women's roles in society. Nevertheless, even while expressing unpopular opinions in her journalistic production Pardo Bazán was able to create and later maintain a place for herself in the intellectual circles of her times. Scholars have explored many aspects of Pardo Bazán's writings that examine the plight of women in nineteenth-century Spain, including the ways that her short fictional works employ unique narrative designs and contestatory strategies to subtly question the hegemony of patriarchal cultural. It is within this line of inquiry that the present study also fits. ${ }^{1}$

This essay analyzes and draws connections between two short stories both penned by Emilia Pardo Bazán around the turn of the twentieth century. In both

\footnotetext{
${ }^{1}$ Some of the most important studies that analyze these strategies are those by Joyce Tolliver (1998), Maryellen Bieder (1993), Susan McKenna (2009), Joan Hoffman (1999) and myself (2010). 
tales there are small objects that symbolically allude to women's objectification in the patriarchal society of the time. The first tale "Primer amor" (1883) is the narration of an adult man who tells the story of his first love, a scenario that takes place in his early teens when he falls in love with a miniatura (daguerreotype). This tale is told in the first person by the story's protagonist. The second story, "La argolla" (1902), narrates the tale of a young woman who is given a beautiful gemstone bracelet as a gift by a wealthy businessman with whom she has agreed to move to England. This tale is told by a third-person narrator while the vast majority of it is an internal monologue focalized through the perspective of the story's protagonist, a young working-class woman Leocadia. The dialogue created between these two tales is noteworthy for a number of reasons, including the narrative techniques employed and their critical portrayals of romantic relationships. It is my contention that both tales critique the objectification of women by the patriarchal society of the time by linking society's tendency to objectify women with symbolic references to female confinement.

In the story "Primer amor", a first-person narrator tells the story of his first love, recalling a period in his life when he was just thirteen years old. One of the boy's favorite pastimes was looking through the intriguing objects in his aunt's dresser drawers, and he is especially fascinated by a miniatura of a young, beautiful woman that he finds there. He becomes infatuated with it the first time he sees it, and claims to think of nothing else for the following months. The description of the relationship that the pubescent boy establishes with this inanimate object is described as if it were a courtship between two young people: at the beginning he visits her often in his aunt's dresser drawer, and eventually their relationship develops to the point where they are practically inseparable. The initial description of the portrait is especially sensual in nature:

no era una virgencita cándida, capullo a medio abrir, sino una mujer en quien ya resplandecía todo el fulgor de la belleza. Tenía la cara oval, [...] los labios carnosos, entreabiertos y risueños; los ojos lánguidamente entornados, y hoyuelo en la barba, que parecía abierto por la yema del dedo juguetón de Cupido. Su peinado era extraño y gracioso [...]. Este peinado antiguo, que arremangaba en la nuca, descubría toda la morbidez de la fresca garganta, donde el hoyo de la barbilla se repetía más delicado y suave. (Pardo Bazán 1990a: 286)

It is noteworthy that the description begins with what the woman is not: a candid virgin, a bud half-opened, but rather, it explains that she is a mature woman. The depiction of this image contrasts with the majority of the female characters in Pardo Bazán's short fiction, which tend to be quite innocent and virginal. The protagonist continues by describing in detail the dress that the woman is wearing, noting "dos escándalos de nieve, por entre los cuales serpenteaba un hilo de perlas, no sin descansar antes en la tersa superficie del satinado escote" (Pardo Bazán 1990a: 286). The sensual images that the description of the string of pearls amongst the figure's breasts conjures up must 
have been quite scandalous for one of Pardo Bazán's contemporary readers. Immediately following this description of her dress, the narrator also observes that a woman wearing that same dress in the present moment would cause quite a scandal, implying that some decades prior to the timeframe in which the action takes place women were given more freedom to dress more provocatively than the women in the present moment.

The attraction that the narrator feels for the miniatura is consistently juxtaposed to the traits of the boy's aging spinster aunt, including her grey hair, saggy skin and sunken mouth lined by a faint mustache on her upper lip. These marked contrasts function in two ways: firstly, as a foreshadowing of the climax, in which the narrator discovers that the miniatura that he so adores is actually an image of his aunt taken some years before, a detail that the reader is likely to have surmised well in advance this moment in the story. Secondly, these contrasting representations highlight the immense cultural capital that female youth and beauty held in this timeframe, given that the young protagonist becomes completely enamored by an inanimate object's aesthetics.

The dichotomy that we see in the narrator's opposed reactions to the two different representations of his aunt is paralleled by the duality of the objectification of the image in the miniatura. On the one hand, the narrator describes the image in extremely sensual terms but at the same time the woman adheres to the ángel del hogar paradigm, ${ }^{2}$ restricted to complete passivity and an enclosed space. ${ }^{3}$ Indeed, in a description of the miniatura, the narrator underscores the image's confinement: "desde el fondo de su cárcel de tela" (Pardo Bazán 1990a: 287). ${ }^{4}$

There are two other moments in which female objectification is brought to the fore in "Primer amor." As the narrator reflects on the profound effect that the miniatura had on him, he recalls:

Frecuentemente, en las Ilustraciones, en los grabados mitológicos del comedor, en los escaparates de las tiendas, sucedía que una línea gallarda, un contorno armonioso y elegante, cautivaba mis miradas precozmente artísticas. (Pardo Bazán 1990a: 1154)

This reference enumerates the various types of female images that were part of the male visual culture of the time, thus foregrounding the training that men

\footnotetext{
${ }^{2}$ The ángel del hogar paradigm was an ideal model of womanhood to which all bourgeois women were expected to conform during the second-half of the nineteenth century. This paradigm required women to be innocent, pure, devout Catholics and to dedicate themselves entirely to their roles of wife and mother. See Aldaraca's (1991) first chapter for a more detailed discussion of this paradigm.

3 In his analysis of "First love" Dana Livingston cites this same duality but sees it as contradictory (1997: 267).

${ }^{4}$ Livingston also discusses the objectivity of the female figure: "The image of the erotic young woman, reflects [...] an individual subjected by power relations that posit her as a passive object of desire. The young boy, on the other hand, plays an antithetic role where in he must manifest a more active sexuality" (1997: 267).
} 
were given by simply viewing the images around them, while it also brings to light the prominence of the male gaze in this social milieu. The critic Elaine Showalter elucidates its dual nature:

The male gaze is $[\ldots]$ both self-empowering and self-endangering, for what lies behind the veil is the specter of female sexuality, a silent but terrible mouth that may wound or devour the male spectator. (Showalter 1991: 146)

The boy's choice to fall in love with an object clearly eliminates any possibility of an expression of female sexuality in this relationship.

This specter of female sexuality is alluded to in the story when it is one of the narrator's younger female cousins who attempts to give him a rosebud during a brief encounter between the two. The narrator's reaction to this overt gesture of active subjectivity is complete rejection; he immediately throws the rose bud back at her. The protagonist's disgusted reaction to his cousin stands in stark contrast to his adoration for the miniatura. The primary difference that seems to explain this strong reaction is that his cousin takes an active role, while the miniatura is entirely passive as an inanimate object and thus he is sure to be able to maintain complete control over her. The miniatura also represents sexuality in a restricted environment; the woman's sensual traits are wholly contained within the two-dimensional image of her. Therefore, the narrator is capable of seeing a woman as a sexual object, as he demonstrates in his references to the many images he has seen of women in public spaces. What he is not comfortable or familiar with, however, is seeing a woman as a sexual subject, what his cousin proposed by offering him the rose bud, an action he immediately rejects.

Another allusion to females being treated as objects is made when the narrator's friends ask him: "si yo no escogería también $<<$ mi niña $>>$ con quien cartearme" (Pardo Bazán 1990a: 288). In this case the girl's function as a direct object in the grammatical structure of the sentence shows the entirely passive role she was expected to play in the social custom of courtship during this time.

The aunt's response to her nephew's possession of her miniatura at the end of the story gives insight into the female position: “¡Hoy en día nadie pinta miniaturas!... Eso se acabó... y yo también me acabé y no soy lo que ahí aparece!" (Pardo Bazán 1990a: 290). Her final words, that she is not what appears in the image, not only denote the physical changes that she has suffered through aging but also, she refers to the objectification that the image has suffered in her nephew's hands. She is more than what appears in the portrait, a twodimensional image of her cannot fully represent who she is. Thus, the story suggests that women are more than what visual images of them can represent. Through the reference to the visual culture of periodicals marketed to males laden with images of women, the tale censures the practice of valuing women based entirely on their physical appearance. This story offers an implicit social critique of a culture that produces a boy who adores an image of a woman as if 
it were a true flesh and blood being, while he rejects the advances of a young woman his age.

The story ends when the protagonist finally faints because he is so overtaken by emotion after removing the glass cover from the miniatura and smelling the locks of real hair that adorn it. The final scene is melodramatic, as is the entire story to a certain degree, especially if we consider that the narrator tells the story as an adult, looking back to this first love of his youth. But what is most surprising about the tale is that the narrator never alludes to the fact that his falling deeply in love with an inanimate object is anything out of the ordinary. I would suggest that it is precisely this enigmatic aspect of the story that makes it so unique and fascinating. If, even as an adult, the protagonist makes no mention of the fact that his "first love" was atypical, then the story implies that a relationship between a man and a real woman must not be much different than the one that the protagonist describes in this tale. It is the narrative framing device that makes it clear that several years have passed between the events of the narration and the narrator's telling of it. Moreover, in the middle of the tale the reader is reminded that it is an adult man telling the story when the narrator mentions that the cousin who attempted to give him the rosebud is now married with three children, and seems to still be cross with him for having rejected her proposal that day. As I have asserted in a previous study, these narrative framing devices in Pardo Bazán's short fiction: "subtly call into question patriarchal social customs and also highlight the important role of the reader in interpreting a story" (Walter 2007: 18).

In the story "La argolla" a working-class girl of very modest means, Leocadia, realizes that accepting a proposal to run off and live with a wealthy merchant Gaspar, will only lead her to lose the little bit of freedom that she currently has. Immediately after accepting the merchant's proposal Leocadia is very excited, and she dedicates a great deal of time to imagining all of the beautiful clothing that she will wear and how luxurious her new life will be. But as she ponders the beautiful diamond bracelet that Gaspar gave her as a symbol of their agreement to move to England together, the reality of her situation sets in. ${ }^{5}$ She recognizes that the bracelet is not a sign of her freedom, but rather a sign of her future imprisonment. She thinks of a young female friend who recently married, and realizes that if she runs away with Gaspar, she will never be able to marry. Instead of opening herself up to a wealth of possibilities, she recognizes that if she accepts the proposal, she's actually cutting herself off from the one opportunity that she has to be a respectable woman-marriage. The lack of autonomy to which accepting the proposal will lead is clear from the description

\footnotetext{
${ }^{5}$ It is important to take note of the multiple meanings of the term "argolla" in Spanish: it can mean simply "a bracelet," which is the surface meaning in the text. The figurative meaning, however, is: "Sujeción, cosa que sujeta a uno a la voluntad de otro" (Pardo Bazán 1990b: 187) according to the Diccionario de la Real Academia.
} 
of the bracelet on her wrist: "que acababa de ceñir a su muñeca" (Pardo Bazán 1990b: 406).

The descriptions of the jewels that she hopes to own also elucidate the future state she could find herself in: "aros de rubíes sangrientos ...cadenas de eslabones de oro, entreverados con lágrimas de perlas"(Pardo Bazán 1990b: 406). There are several symbolic allusions to suffering in this sentence: the rubies would be bloody; she may wear chains, albeit golden ones; and finally the pearls she could wear are tear-shaped. All of these images spark a bitter thought in the mind of the protagonist: she has some vague memory of a jewel being associated with slavery in primitive times, but she quickly pushes that idea from her mind, and focuses again on the luxurious belongings this new life with Gaspar will afford her. The symbolic images of imprisonment, however, resurface toward the end of the text. When Leocadia receives a letter from Gaspar, she approaches the "ventana enrejada" to read it, and the narrator reminds the reader once again that the window has bars when Leocadia approaches it to tear up and throw the letter through it. The prison-like image of a window covered with bars as a key element of the setting alludes to what Leocadia's fate will be if she chooses to accept the wealthy merchant's proposition.

On a symbolic level within the tale, the "argolla" of the title represents the objectification of Leocadia by her suitor. He sees her as a beautiful jewel that he can hang on his arm, just as she adorns hers with the beautiful bracelet he has given her. While she contemplates the beautiful things that she will own in her new life with Gaspar, the tale suggest that Gaspar has chosen Leocadia for her aesthetic appeal - she is described as possessing "regia hermosura" (Pardo Bazán 1990b: 405). The narrator gives the reader no details about any relationship that Leocadia and Gaspar share, in fact the narration explains that Gaspar has just returned from one of his many trips abroad, establishing that the two are mere acquaintances.

Similar to the contrasts established in "Primer amor" between the sensual young woman and the aging aunt, "La argolla" also juxtaposes Leocadia's young, nubile body with that of the aging and overweight Gaspar. In the opening of the story Leocadia is described as possessing "regia hermosura, mariposa de intensos colores, rompía ya el basto capullo" (Pardo Bazán 1990b: 405), implying that she is just becoming a woman. In contrast to her youth and beauty, the exposition of the story closes with an abrupt shift that details Gaspar's decaying physical appearance:

Su barba ya canosa, lustrada de aceite perfumado; su boca, de labios gordos; sus dientes plomizos, restaurados por medio de toquecitos de oro; sus mejillas llenas y encarnadas; su abdomen de ricachón... (Pardo Bazán 1990b: 407)

The emphasis placed on their disparate ages and physical appearances subtly censures the inequity of this union, in which the rich merchant is essentially able to 'buy' Leocadia's companionship, very much as he purchased 
the diamond bracelet for her. Immediately after this description of Gaspar, there is a case of indirect free style in which Leocadia's mental state is made clear: "¿Qué tipo tan diferente de lo que a menudo, al oír música, después de leer versos, o en la capilla, entre el olor del incienso soñaba Leocadia!" (Pardo Bazán 1990b: 407). This use of free indirect discourse serves to show through Leocadia's perspective that Gaspar is not the type of suitor she had hoped for, and also creates the opportunity for a more engaged reader response. ${ }^{6}$ This section of the story ends with Leocadia thinking to herself "solo faltaban seis días para la exclavitud"7 (Pardo Bazán 1990b: 407), a statement that clearly shows that she has now fully understood what the acceptance of Gaspar's proposal will mean for her.

The wealth of lavishly visual images that populate most of the lines of the tale show the importance that Leocadia attributes to the aesthetic world. She seems obsessed with the idea of owning beautiful things, rather than the wornout and simple clothing that she has to wear now. In fact, it is her desire to adorn herself with beautiful clothing and jewelry that serves as her main reason for wanting to run off with Gaspar as all she can think of from the moment she accepts the proposal is how beautiful and luxurious her new clothing and accessories will be. In a very intriguing passage focalized through Leocadia's perspective, she imagines in detail what all of these fabrics will feel like against her skin:

Su cutis fino, de puro raso, percibía el contacto de la batista, la caricia muelle del encaje; su garganta, la tibia atmósfera que crean los rizados plumajes... (Pardo Bazán 1990b: 406)

She is in rapture thinking about carnal contact with her new clothing, rather than with her companion, Gaspar.

In her famous essay "La mujer española," Pardo Bazán critiques women's devotion to their appearance:

La mujer, al ser frívola, al vivir entre el modista y el peluquero, no hace sino permanecer en el terreno a que la tiene relegada el hombre y sostener su papel de mueble de lujo. (Pardo Bazán 1999: 95)

Thus, Pardo Bazán insists that the role of the frivolous female is one created by men, and women who fit into this paradigm are allowing themselves to be molded into the superficial and beautiful objects that men want them to be. With

${ }^{6}$ The critic Kathy Mezei has suggested that free indirect discourse: "can set up two quite contrary positions: narratorial irony toward and distance from the character-focalizer, as in Madame Bovary, or narratorial empathy towards the character(s), which results in a more engaged reader response, as in Mrs. Dalloway" (1996: 69).

7 Pardo Bazán's admiration of John Stuart Mill, author of “The Subjection of Women" (1869) (translated to Spanish as "La esclavitud de la mujer") is well-known. See her essay titled "Stuart Mill" included in the edited volume by Gómez-Ferrer La mujer española y otros escritos (Pardo Bazán 1999: 215-230). 
this, she proposes that women reject this role that men have defined for them, a role that leaves them in a position of passive object, or "mueble de lujo," as our author describes it. In this story Leocadia ultimately does refuse this traditional role defined for her by rejecting the proposition of the rich merchant. The story concludes with a daring and quite surprising action by Leocadia, she throws her beautiful bracelet to the ground and stomps on it. She has finally recognized both the symbolic and real meaning of the bracelet. Through her acceptance of it she relegates herself to an inferior position, in which she becomes enslaved to the man who gave it to her. By destroying the beautiful bracelet, her sole prized possession, she is also taking away some of her own aesthetic appeal, and by doing so, taking a step towards rejecting her physical appearance as her only source of value.

"La argolla" stands out as one of the few stories penned by Pardo Bazán in which the reader is given great insight into a female protagonist's psychology. While the story is told by a third-person narrator, the vast majority of it is an internal monologue focalized through Leocadia's perspective. ${ }^{8}$ Clearly Leocadia has been physically objectified by her suitor, but she rejects this role as attractive mistress to a wealthy man, and instead decides to create her own destiny. The narrative perspective of the tale aligns well with Leocadia's daring stance at the end of the story, in which she does what she wants to regardless of the consequences. The story offers no specific information as to what Leocadia's future holds, but it is clear from her act of self-determination in the resolution of this tale that she has elected to forge her own path, which she has already begun to construct by rejecting her role as passive object, and becoming an acting subject when she chooses to destroy the bracelet.

Through the symbolic use of small objects and references to spatial limitations, both of these stories succeed in highlighting the link between women's objectification and their concomitant confinement. At first glance it may not be obvious that these stories offer social critiques, but through the careful analysis of narrative techniques and perspective as well as descriptive language and symbolism, one can uncover their 'muted' story. ${ }^{9}$ The dominant story of "First Love" is simply a boy recalling the first time he fell in love; in "La argolla" the reader is presented with a pivotal moment in a woman's life in which she decides to reject her suitor's proposal. As I assert in an earlier study:

\footnotetext{
8 This is not surprising given that Quesada Novás asserts that the most rebellious female characters in Pardo Bazán's short stories are precisely the ones who are given the opportunity to tell their own stories in the tale's narrative design (2004: 193).

${ }^{9}$ According to Elaine Showalter in her seminal study "Feminist Criticism in the Wilderness": “...women's fiction can be read as a double-voiced discourse, containing a 'dominant' and a 'muted' story, what Gilbert and Gubar call a 'palimpsest.' I have described it elsewhere as an object/field problem in which we must keep two alternative oscillating texts simultaneously in view" (1981: 204).
} 
the short narratives of our author, albeit in coded and subtle ways, open up a space in their shifting and multi-layered discourse for the creation of female subjectivity. (Walter 2010: 167)

Indeed, in both of these tales a space is created in which female subjectivity is explored, while, at the same time, they highlight the pernicious effects that result from the objectification of women.

\section{BIBLIOGRAPHY}

AlDARACA, B. (1991), El ángel del hogar: Galdós and the Ideology of Domesticity in Spain, Chapel Hill, University of North Carolina UP.

BIEDER, M. (1993), «Plotting Gender/Replotting the Reader: Strategies of Subversion In the Stories by Emilia Pardo Bazán», Indiana Journal of Hispanic Literatures, 2.1, 137-156.

HOFFMAN, J. (1999), «Torn Lace and Other Transformations: Rewriting the Bride's Script in Selected Stories by Emilia Pardo Bazán», Hispania, 82, 238-245.

LIVINGSTON, D. (1997), «First Love? Marginal Sexualities in a Short Story by Emilia Pardo Bazán», Letras Peninsulares, 10.2, 265-279.

MCKENNA, S. (2009), Crafting the Female Subject: Narrative Innovation in the Short Fiction of Emilia Pardo Bazán, Washington, Catholic University Press.

MezeI, K. (1996), «Free Indirect Discourse, Gender and Authority in Emma, Howards End, and Mrs. Dalloway», in Ambiguous Discourse: Feminist Narratology and British Women Writers, Mezei, K. (ed.), Chapel Hill, North Carolina UP, 66-92.

PARDOBAZÁN, E. (1999), La mujer española y otros escritos, Gómez-Ferrer, G. (ed.), Madrid, Cátedra.

PARdo BAZÁN, E. (1990a), «Primer amor», en Cuentos completos, 1 vol., Paredes Núñez, J. (ed.), La Coruña, Fundación Pedro Barrie de la Maza, Conde de Fenosa, 286-290.

PARDO BAZÁN, E. (1990b), «La argolla», en Cuentos completos, 2 vol., Paredes Núñez, J. (ed.), La Coruña, Fundación Pedro Barrie de la Maza, Conde de Fenosa, 405-407.

RAE (1998), Diccionario de la Real Academia Española, 2 vols., Madrid, Real Academia Española.

Quesada Novas, Á. (2004), El amor en los cuentos de Emilia Pardo Bazán, Alicante, Publicaciones de la Universidad de Alicante.

SHOWALTER, E. (1981), «Feminist Criticism in the Wilderness», Critical Inquiry, 8.2, 179-205.

SHOWALTER, E. (1991), Sexual Anarchy: Gender and Culture at the Fin de Siecle, New York, Viking.

TOLLIVER, J. (1998), Cigar Smoke and Violet Water: Gendered Discourse in the Stories of Emilia Pardo Bazán, Lewisburg, Bucknell UP.

WALter, S. (2007), «The Use of Narrative Frames in Four Tales by Emilia Pardo Bazán», Hispania, 90.1, 10-20.

WALTER, S. (2010), From the Outside Looking In: Narrative Frames and Narrative Spaces in the Short Stories of Emilia Pardo Bazán, Newark, Juan de la Cuesta. 